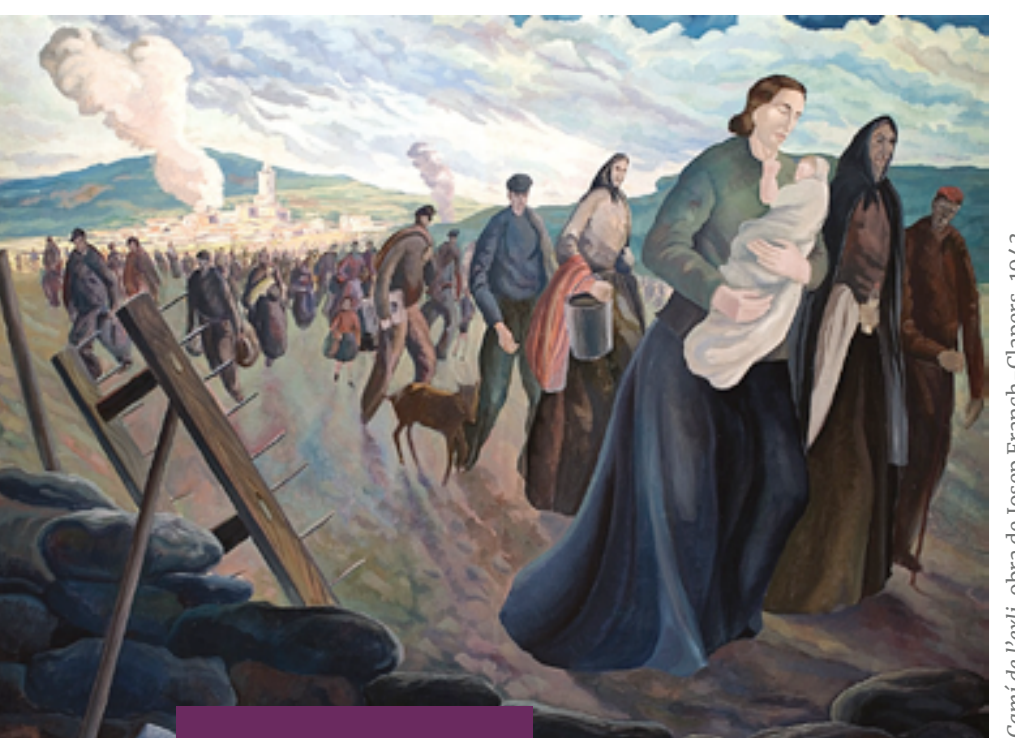

FIGURAS REVISTA ACADÉMICA DE INVESTIGACIÓN

ISSN 2683-2917

Vol. 1, núm. 2, marzo-junio 2020

https://doi.org/10.22201/fesa.figuras.2020.1.2

Esta obra está bajo una licencia

Creative Commons Atribución-NoComercial-

Compartirlgual 4.0 Internacional

\section{Oriundos y peregrinos}

(D) Jonathan López Romo

https://doi.org/10.22201/fesa.figuras.2020.1.2.109

Me he dispuesto a compartirles mis apuntes sobre dos libros que en este año conversan sobre la relación entre España y México durante el -cada vez más lejano- siglo Xx. Independientemente de la efeméride (80 años del exilio español hacia nuestro país), esta conexión produjo un inconmensurable -con humilde atrevimiento lo califico- patrimonio cultural que definió un norte en diversos escenarios de nuestra sociedad. En la incertidumbre actual, es esperanzador que nos reencontremos con el "pasado cercano" en dos novedades editoriales que se relacionan, paralelamente, con la migración y el escape (humano e ideológico) de un importante número de españoles, anónimos y reconocidos, que encontraron tierra fértil y firme para comenzar de nuevo.

\section{Oriundos*}

La Real Academia de la Lengua Española define la voz "oriundo" como el adjetivo que se debe usar cuando el sujeto "trae su origen de algún lugar" -empezar desde cero en otro campo-. Fernando Fernández (Ciudad de México, 1964) "da voz" a los que, en palabras del autor, forman "un mundo propio en el país que los acoge"; en Oriundos (Cataria Ediciones) se cierra un capítulo dentro de la obra de este autor: el peregrinar de una década para definir y estructurar este proyecto personal y, por consecuencia, literario.

Leer este nuevo libro es una invitación a que el lector se reencuentre con las raíces y a cuestionarnos sobre nuestro origen. Este compendio de anécdotas de migrantes asturianos, que han traído "su origen" a nuestro país, nos lleva por pasajes muy diversos: abuelos, tíos, amigos de la familia de desconocido origen, pero reconocido cariño; más tíos, aquellos que se caracterizan por sus modos o por sus desventuras; los amores que quedaron inconclusos y un retrato escolar.

\section{Fernando Fernández nos expone una vida cotidiana: una Ciudad de México cada vez más lejana y una España ya desconocida para mi generación y las posteriores.}

De Gijón a Ciudad de México, Oriundos es un peculiar universo: reunido en 30 textos -anécdotas, crónicas y encuentros- en donde se juega con el tiempo y el espacio pero, en este trabajo en particular, es necesario involucrarse con los personajes que, en ocasiones, pareciera que se despiden pero regresan para complementar el relato de otros (a este punto, cabe agregar el detalle que el editor-autor nos da al incluir una postal con una fotografía en donde los principales actores se detallan). Fernando Fernández 
- con humildad refiero- nos presenta un trabajo en donde su familia se convierte, también, en la nuestra. Va más allá, no sólo es un recuento y reencuentro familiar, nos expone una vida cotidiana: una Ciudad de México cada vez más lejana y una España ya desconocida para mi generación y las posteriores; serie de personajes dignos de tener su propio relato en donde, como lectores, podríamos evocarles nuevas aventuras. Además de ser un documento atractivo para documentar el fenómeno social de las migraciones en nuestro país, Oriundos es una crónica de necesaria consulta para el académico que también se dedica a la observación de la sociedad desde su ámbito familiar: los factores que afectan al ser humano migrante y generan una identidad.

\section{España peregrina**}

La misma academia define la palabra "peregrino" como la persona que "anda por tierras extrañas" y, en otra de sus acepciones, "que procede de un país extraño". ¿Cómo fue la visión de los errantes españoles que llegaron a nuestro, para ellos, "extraño país" y para los mexicanos que los recibieron provenientes de una "extraña tierra"? En este facsímil de la primera revista cultural impulsada por los exiliados republicanos en México, España peregrina (editada por la UNAM y El Equilibrista) nos adentra a un encuentro con las voces que quisieron ser calladas en su tierra, pero que encontraron reposo en la nuestra.

\section{España peregrina nos invita a sentir cómo la herida del exilio encontró en nuestro país una cicatrización sincera.}

La aventura de enfrentarse, contextualizar y encontrarse con la casi idéntica reproducción de un documento como lo es la edición de 1940 de España peregrina es encontrarnos con nombres conocidos para ambos mundos (Lorca, Machado, Picasso, Paz, Reyes, Halffter, Mistral, Felipe, Larrea, Ortega y Gasset...) que actualmente están escritos -jugando a los lugares comunes de la épica- en "letras de oro", pero que, para la época que nos presenta el libro, o eran jóvenes promesas o prodigios "en bruto" que años después detonaron. El ejercicio, un viaje al pasado, de leer los años cuarenta en esta revista cultural es también aprender a apreciar el "cómo se leía" de la época: el manejo tipográfico, las cajas de texto; el acomodo de las secciones de la publicación y, asimismo, el de la publicidad (en donde podremos encontrar algunas de -las otras-instituciones que los españoles instalaron en nuestro país como el Instituto Luis Vives o la Academia Hispano Americana); entre otros elementos que formaron parte de esta publicación (partituras, postales y otros documentos sueltos).

Como lectores, aficionados o académicos, es indispensable "darle posada" en nuestro librero a este título. España peregrina nos invita a recorrer con otra perspectiva el Centro Histórico de Ciudad México, así como sus alrededores, y poder sentir cómo la herida del exilio encontró en nuestro país una cicatrización sincera: (re) encuentro de dos mundos. -

\section{Referencias}

*Fernández, Fernando. 2018. Oriundos. México: Cataria Ediciones.

**Larrea, Juan, Francisco Giner de los Ríos, Pedro Garfias y Juan Vicens (colaboradores). 2019. España peregrina. México: UNAM-El Equilibrista. 